\title{
Cytotoxic Potential of Biogenic Zinc Oxide Nanoparticles Synthesized From Swertia chirayita Leaf Extract on Colorectal Cancer Cells
}

OPEN ACCESS

Edited by: Suresh K. Verma,

Uppsala University, Sweden

Reviewed by:

Nagendra Kumar Kaushik, Kwangwoon University, South Korea Shalini Trivedi,

Masaryk University, Czechia

*Correspondence: Srinivas Patnaik srinivas.patnaik@kittbiotech.ac.in

Specialty section: This article was submitted to

Nanobiotechnology,

a section of the journal Frontiers in Bioengineering and

Biotechnology

Received: 02 October 2021 Accepted: 23 November 2021 Published: 15 December 2021

Citation:

Berehu HM, S A, Khan MI,

Chakraborty R, Lavudi K, Penchalaneni J, Mohapatra B, Mishra A and Patnaik S (2021) Cytotoxic Potential of Biogenic Zinc Oxide Nanoparticles Synthesized From Swertia chirayita Leaf Extract on Colorectal Cancer Cells. Front. Bioeng. Biotechnol. 9:788527. doi: 10.3389/fbioe.2021.788527
Hadgu Mendefro Berehu ${ }^{1}$, Anupriya $S^{1}$, Md Imran Khan ${ }^{1}$, Rajasree Chakraborty ${ }^{1}$, Kousalya Lavudi ${ }^{1}$, Josthna Penchalaneni ${ }^{2}$, Bibhashee Mohapatra ${ }^{1}$, Amrita Mishra ${ }^{1}$ and Srinivas Patnaik ${ }^{1 *}$

${ }^{1}$ Disease Biology Laboratory, School of Biotechnology KIIT Deemed to Be University, Odisha, India, ${ }^{2}$ Department of Biotechnology, Sri Padmavati Mahila Visvavidyalam, Tirupati, India

Chemotherapy side effects, medication resistance, and tumor metastasis impede the advancement of cancer treatments, resulting in a poor prognosis for cancer patients. In the last decade, nanoparticles (NPs) have emerged as a promising drug delivery system. Swertia chirayita has long been used as a treatment option to treat a variety of ailments. Zinc oxide nanoparticles (ZnO-NPs) were synthesized from ethanolic and methanolic extract of S. chirayita leaves. ZnO-NPs were characterized using UV-visible spectroscopy, Fourier transform infrared spectroscopy (FIIR), scanning electron Microscopy (SEM), highresolution transmission electron microscopy (HRTEM), and X-ray diffraction (XRD). Its anticancer activities were analyzed using cytotoxicity assays [MTT assay and acridine orange (AO) staining] and quantitative real-time PCR (qRT-PCR) using colorectal cancer (CRC) cells (HCT-116 and Caco-2) and control cells (HEK-293). The ZnO-NPs synthesized from the ethanolic extract of $S$. chirayita have an average size of $24.67 \mathrm{~nm}$, whereas those from methanolic extract have an average size of $22.95 \mathrm{~nm}$ with a spherical shape. MTT assay showed NPs' cytotoxic potential on cancer cells (HCT-116 and Caco-2) when compared to control cells (HEK-293). The $\mathrm{IC}_{50}$ values of ethanolic and methanolic extract $\mathrm{ZnO}-\mathrm{NPs}$ for HCT-116, Caco-2, and HEK-293 were $34.356 \pm 2.71$ and $32.856 \pm 2.99 \mu \mathrm{g} / \mathrm{ml}$, $52.15 \pm 8.23$ and $63.1 \pm 12.09 \mu \mathrm{g} / \mathrm{ml}$, and $582.84 \pm 5.26$ and $615.35 \pm 4.74 \mu \mathrm{g} / \mathrm{ml}$, respectively. Acridine orange staining confirmed the ability of ZnO-NPs to induce apoptosis. qRT-PCR analysis revealed significantly enhanced expression of E-cadherin whereas a reduced expression of vimentin and CDK-1. Altogether, these results suggested anti-cancer properties of synthesized ZnO-NPs in CRC.

Keywords: biogenic, colorectal cancer, zinc oxide nanoparticles, Swertia chirayita, cytotoxicity

\section{INTRODUCTION}

Colorectal cancer (CRC) is the second most fatal cancer and the third most common malignant tumor in the globe. In 2018, 1.8 million new CRC cases were recorded, with around 900,000 fatalities (Bray et al., 2018), and the number of new cases is expected to rise to nearly 2.5 million by 2035 (Dekker et al., 2019). Adjuvant radiotherapy and chemotherapy, together with surgery, help extend the patient's life. However, the abovementioned common treatments have drawbacks, including drug 
resistance and adverse effects like fatigue, alopecia, anemia, etc. due to non-specific distribution of drugs (Banerjee et al., 2017; Van der Jeught et al., 2018). These difficulties pushed scientists to explore different approaches for cancer therapy with fewer side effects. The use of nanotechnology-based techniques in cancer therapy has yielded encouraging outputs. As a result, possible treatment alternatives that are efficient, affordable, and have excellent biocompatibility must be sought.

In the recent few decades, nanotechnology's implications have progressed to a higher level. Various forms of organic and inorganic nanoparticles, particularly metal nanoparticles and their composites, have been investigated extensively and used in a variety of applications (Verma et al., 2018a, 2016). Metal oxide nanoparticles have shown to have potential and a broad range of applications in the biomedical area, including anticancer drug/ gene delivery, cell imaging, and biosensing (Khalil et al., 2017; Mishra et al., 2017; Verma et al., 2018b). Zinc is well regarded as an essential trace element that may be found in all human tissues, such as the brain, muscle, bone, and skin. Zinc participates in metabolic activities and has an essential role in nucleic acid and protein synthesis, neurogenesis, hematopoiesis, and as a major cofactor of different enzyme systems (Ruszkiewicz et al., 2017). Zinc oxide nanoparticles ( $\mathrm{ZnO}-\mathrm{NPs}$ ) have distinctive physical and chemical properties, due to their broad bandgap and high exciton binding energy. It is one of the most significant metal oxide nanoparticles and is being widely used in a variety of disciplines (Ruszkiewicz et al., 2017).

Nanoparticles have entirely unique properties since they have distinct features such as size, shape, and distribution. There are several procedures available for the fabrication of nanoparticles, including chemical-mediated, radiation-mediated, and electrochemical- and microwave-assisted processes, as well as green approaches (Gan and Li, 2012; Kumari et al., 2019). Biogenic metallic nanoparticles are highly water-soluble, biocompatible, and less toxic. Several studies have shown that various plant extracts are used to synthesize $\mathrm{ZnO}-\mathrm{NPs}$; for instance, aqueous extract of Deverra tortuosa (Selim et al., 2020), leaf extracts of Cassia fistula and Melia azedarach (Naseer et al., 2020), Cassia auriculata flower extract (Seshadri et al. 2021), and Hibiscus rosa-sinensis leaf extract (Divya et al., 2013) were employed as reducing agents for zinc nitrate to fabricate $\mathrm{ZnO}-\mathrm{NPs}$.

Swertia chirayita, a centuries-old plant, is a perennial herb endemic to the temperate Himalayan area. Because of the annual/ biennial plant found in Nepalese woods, it is often referred to as Nepali neem (Aleem and Kabir, 2018). This herb or shrub grows up to a height of $1.5 \mathrm{~m}$ in the sub-temperate area of the Himalaya. In India, 40 species of Swertia have been registered so far (Kumar and Van Staden, 2016). S. chirayita is well-known for its bitter flavor and has a long history of usage in traditional medicine. It has an antimicrobial effect that works against both Gram-positive and Gram-negative bacteria. According to the Unani lists, different parts of the plant are applied as medicine for different disorders such as liver and cardiac diseases, cough, scanty urine, melancholia, dropsy, sciatica, and skin diseases. It is also used as a tonic in gastrointestinal illnesses including dyspepsia/anorexia, constipation, anti-malaria (anti-fever), bronchial asthma, etc. (Khanal et al., 2014).

Ahmad et al. (2021) reported that both crude and purified $S$. chirayita extracts significantly reduced cell growth and induced apoptosis, indicating that it had anticancer activities. S. chirayita is a key ingredient in several Ayurvedic medications and is listed in the British Herbal Pharmacopoeia in 1983. Secoiridoid glucosides, swertiamarin, sweroside, gentiopicroside, amarogentin, and amaroswerin, as well as several tetrahydroxyxanthone derivatives, are the major compounds present in S. chirayita (Wawrosch, 2005).

In this study, we synthesized $\mathrm{ZnO}-\mathrm{NPs}$ from ethanol and methanol extracts of $S$. chirayita leaves as capping and reducing agents, while zinc nitrate hexahydrate serves as precursors of zinc oxide nanoparticles. The formation of $\mathrm{ZnO}-\mathrm{NPs}$ was verified and characterized by various microscopic and spectroscopic tests that involve UV-visible spectroscopy (UV-vis), dynamic light scattering (DLS), Fourier transform infrared spectroscopy (FTIR), X-ray diffraction (XRD), scanning electron microscopy (SEM), and transmission electron microscopy (TEM). The main objective of this study was to show the cytotoxic activities of biogenic ZnO-NPs from ethanol and methanol extracts of $S$. chirayita leaves against two CRC cell lines, HCT-116 and Caco-2, and HEK-293 as control. To our knowledge, this is the first report on ethanol and methanol extracts of S. chirayita mediating the synthesis of $\mathrm{ZnO}-\mathrm{NPs}$. Therefore, this study will give alternative therapeutic approaches to use plant-based synthesized nanoparticles that are eco-friendly and cost-effective/affordable.

\section{MATERIALS AND METHODS}

\subsection{Chemicals and Instruments}

Zinc nitrate hexahydrate $\left[\mathrm{Zn}\left(\mathrm{NO}_{3}\right)_{2} \cdot 6 \mathrm{H}_{2} \mathrm{O}\right]$ was purchased from Sigma-Aldrich, United States (CAS \#: 10196-18-6); methanol (CAS \#: 67-56-1) and acridine orange (CAS\#: 10,127-02-3) were obtained from SRL; and ethanol (CAS \#: 64-17-5) and sodium hydroxide (CAS\#: 1310-73-2) were purchased from Merck. The following technologies were used to analyze quantitative and qualitative assessments: gas chromatographymass spectrometry (GC-MS) (Agilent 7890A, United States), UVvisible spectroscopy (Cary $100 \mathrm{UV}$-Vis Spectrophotometer, United States), FTIR (100 Spectrum, Perkin Elmer, Germany), XRD (Rigaku Smart Lab 8A Series, Japan), high-resolution (HR)TEM (HRTEM-JEOL JEM-2100 PLUS, United States), SEM (Carl ZEISS Supra 55, Germany), 96-well plate reader (Epoch microplate spectrophotometer, BioTek, Vermont, United States), heater-stirrer (IKA Magnetic Stirrers Hot Plate, RH digital white, India), rotary evaporator (4003 Heidolph, Germany), bench top fluorescence microscopy (FLoid $^{\mathrm{TM}}$ Cell Imaging Station, United States), and centrifuge (5804/5804R Eppendorf benchtop centrifuge, United States).

\subsection{Cell Lines and Cell Culture Preparation}

Colorectal cancer cell lines (HCT-116 and Caco-2) and control cell line (HEK-293) were procured from the National Centre For Cell Science (NCCS), Pune, India. The cells were cultured in 
Dulbecco's Modified Eagle's Medium (DMEM) added with 10\% heat-inactivated fetal bovine serum (FBS), $1 \%$ of L-glutamine, and $1 \%$ of antibiotics (penicillin/streptomycin) and incubated at $37^{\circ} \mathrm{C}$ in a humidified atmosphere $\left(5 \% \mathrm{CO}_{2}\right)$.

\subsection{Plant Extraction}

Healthy leaves were selected and washed thoroughly with distilled water to get rid of any debris and then dried at room temperature for 5 days. Then, the leaves were ground into a fine powder using a grinder and sieved to get fine powder. The ethanolic and methanolic extracts were prepared as per previous extraction protocols (Hussain et al., 2019). The plant powder ( $1 \mathrm{~g}$ ) was soaked in $100 \mathrm{ml}$ of $80 \%$ ethanol and $90 \%$ methanol and kept in a hot water bath at $50^{\circ} \mathrm{C}$ for 3-4 h. Then, the extract was filtered using a $0.45-\mu \mathrm{m}$ Whatman filter paper and stored at $-20^{\circ} \mathrm{C}$ for further use.

\subsection{Gas Chromatography-Mass Spectrometry Analysis}

The Agilent 7890A Gas Chromatograph (Agilent Technologies, United States) was used to analyze S. chirayita leaf extracts using a fused silica column packed with Elite-5MS capillary column (30 $\mathrm{m}$ in length, $250 \mathrm{~m}$ in diameter, and $0.25 \mathrm{~m}$ in thickness). The carrier gas was pure helium gas (99.99\%) at a pressure of $7.6522 \mathrm{psi}$ and a constant flow rate of $1 \mathrm{ml} / \mathrm{min}$ with an average velocity of $36.445 \mathrm{~cm} / \mathrm{s}$ throughout the $32-\mathrm{min}$ running time. An electron ionization energy technique was used for GC-MS spectrum detection, with a high ionization energy of $70 \mathrm{eV}$ (electron volts) and a scan period of $0.2 \mathrm{~s}$ with fragments ranging from 40 to $600 \mathrm{~m} / \mathrm{z}$.

The injector temperature was kept at $250^{\circ} \mathrm{C}$, and the injection volume was $1 \mathrm{~L}$ (split ratio 10:1). The temperature in the column oven was set at $50^{\circ} \mathrm{C}$ for $1.3719 \mathrm{~min}$, increased at $10^{\circ} \mathrm{C}$ each minute until it reached $250^{\circ} \mathrm{C}$, and then elevated to $325^{\circ} \mathrm{C}$ for $32 \mathrm{~min}$. Phyto-constituents present in the plant extract sample were analyzed by comparing their retention time, peak area, peak height, and mass spectral patterns to those in the National Institute of Standards and Technology (NIST) 08 Mass Spectral Library's spectral database of authentic compounds.

\subsection{Preparation of Green-Synthesized Zinc Oxide Nanoparticles}

Zinc oxide nanoparticles were prepared as described by previous studies with minor modifications (Singh et al., 2011). Zinc nitrate hexahydrate was dissolved in $100 \mathrm{ml}$ of $1 \mathrm{mg} / \mathrm{ml}$ plant extract into 250 - $\mathrm{ml}$ flask and stirred at $70^{\circ} \mathrm{C}$. An aqueous solution of $100 \mathrm{ml}$ of $200 \mathrm{mM}$ sodium hydroxide was added drop wise using a burette into the mixture and stirred constantly for $3 \mathrm{~h}$, using a magnetic stirrer $\left(70^{\circ} \mathrm{C}\right)$. Then, the solution was kept overnight to settle down. The light yellow-colored pellet was collected after discarding the supernatant. The pellet was then washed three times using deionized water and centrifuged at 10,000 rpm for $10 \mathrm{~min}$. The resulting precipitates were then dried in a hot air oven overnight at $100^{\circ} \mathrm{C}$ to form a creamy paste of $\mathrm{ZnO}-\mathrm{NPs}$.
Then, the dried $\mathrm{ZnO}-\mathrm{NPs}$ were finely ground into powder using mortar and pestle.

\subsection{Characterization of Green-Synthesized ZnO-NPs}

The green-synthesized zinc oxide nanoparticles were initially analyzed to know the optical absorption using the Cary $100 \mathrm{UV}$ vis spectrophotometer within the range of $200-800 \mathrm{~nm}$. To identify the functional and phyto-chemical compounds that are involved in the reduction and stability of the synthesized ZnO-NPs, FTIR spectroscopic analysis (FTIR, PerkinElmer, Germany) was used. Further X-ray diffraction analysis was used to validate the crystalline nature and size of the nanoparticles (X-ray diffractometer, Rigaku Smart Lab 8A Series, Japan), equipped with $40 \mathrm{kV} / 30 \mathrm{~mA}$ X-ray, $2 \theta / \theta$ scanning mode, CuKa1-X radiation $(\lambda=$ $1.5406 \mathrm{~A}^{\circ}$ ), and a fixed monochromator in the range of $20^{\circ}-80^{\circ}$. The average size of the nanoparticles was calculated using Scherrer approximation $(\mathrm{Dp}=0.9 \lambda / \beta \operatorname{Cos} \theta)($ Selim et al., 2020). The $\mathrm{ZnO}$ nanopowder was further processed and examined by HR-TEM (HRTEM-JEOL JEM-2100 PLUS, United States). Morphological evaluations were acquired by a scanning electron microscope (Carl ZEISS Supra 55, Oberkochen, Germany).

\subsection{Cell Viability Assay}

The MTT assay [3-(4,5-dimethylthiazol-2-yl)-2,5-diphenyl tetrazolium bromide assay] was done in a 96-well plate to assess the cytotoxicity of the plant extract and ZnO-NPs (Mosmann, 1983). Caco-2 and HCT-116 cell lines and control HEK-293 cells were grown to $\sim 70 \%$ confluence in respective media, and the cells were treated with various concentrations $(5,25,75,150$, and $300 \mu \mathrm{g} /$ $\mathrm{ml}$ ) of crude extract and ZnO-NPs for $24 \mathrm{~h}$. Then, $0.5 \mu \mathrm{g} / \mathrm{ml}$ MTT solution was added to each well and incubated at $37^{\circ} \mathrm{C}$ for $4 \mathrm{~h}$ in the dark before being replaced with $200 \mu \mathrm{l}$ MTT solvent. After $15 \mathrm{~min}$ on a rocker, the optical density of the solution on the plate was measured at $570 \mathrm{~nm}$ with a plate reader (Epoch microplate spectrophotometer, BioTek, Vermont, United States). As a positive control, doxorubicin (57.418 and $63.036 \mu \mathrm{M}$ HCT-116 and Caco- 2 cell lines, respectively) was used (Siddiquah et al., 2018). The experiment was performed three times.

\subsection{Acridine Orange Staining}

The acridine orange (AO) staining method is used to monitor cell death. It is often used to identify acidic vesicular organelles (Lin et al., 2017). It binds into cells nucleic acids, causing double-stranded DNA to glow green and RNA or single-stranded DNA to fluoresce orange-red when observed with fluorescence microscope. The cytoplasm and nuclei glow green under AO labeling, but acidic compartments like lysosomes and auto-phagolysosomes fluoresce bright-red or orange-red (Hwang et al., 2011). Caco-2 cell lines were seeded in six-well plates and treated with crude extracts and their respective $\mathrm{ZnO}$-conjugated NPs. AO is prepared according to the manufacturer's protocol [Sisco Research Laboratories (SRL)]. The medium was removed, and the cells were washed with $1 \mathrm{ml}$ of $1 \mathrm{X}$ PBS, added with $10 \mu \mathrm{l}$ of $12 \mu \mathrm{g} / \mathrm{ml}$ AO working solution, and kept for $5 \mathrm{~min}$ in room temperature. Prior to observation, the cells were washed with $1 \mathrm{ml}$ of $1 \mathrm{X}$ PBS for the 

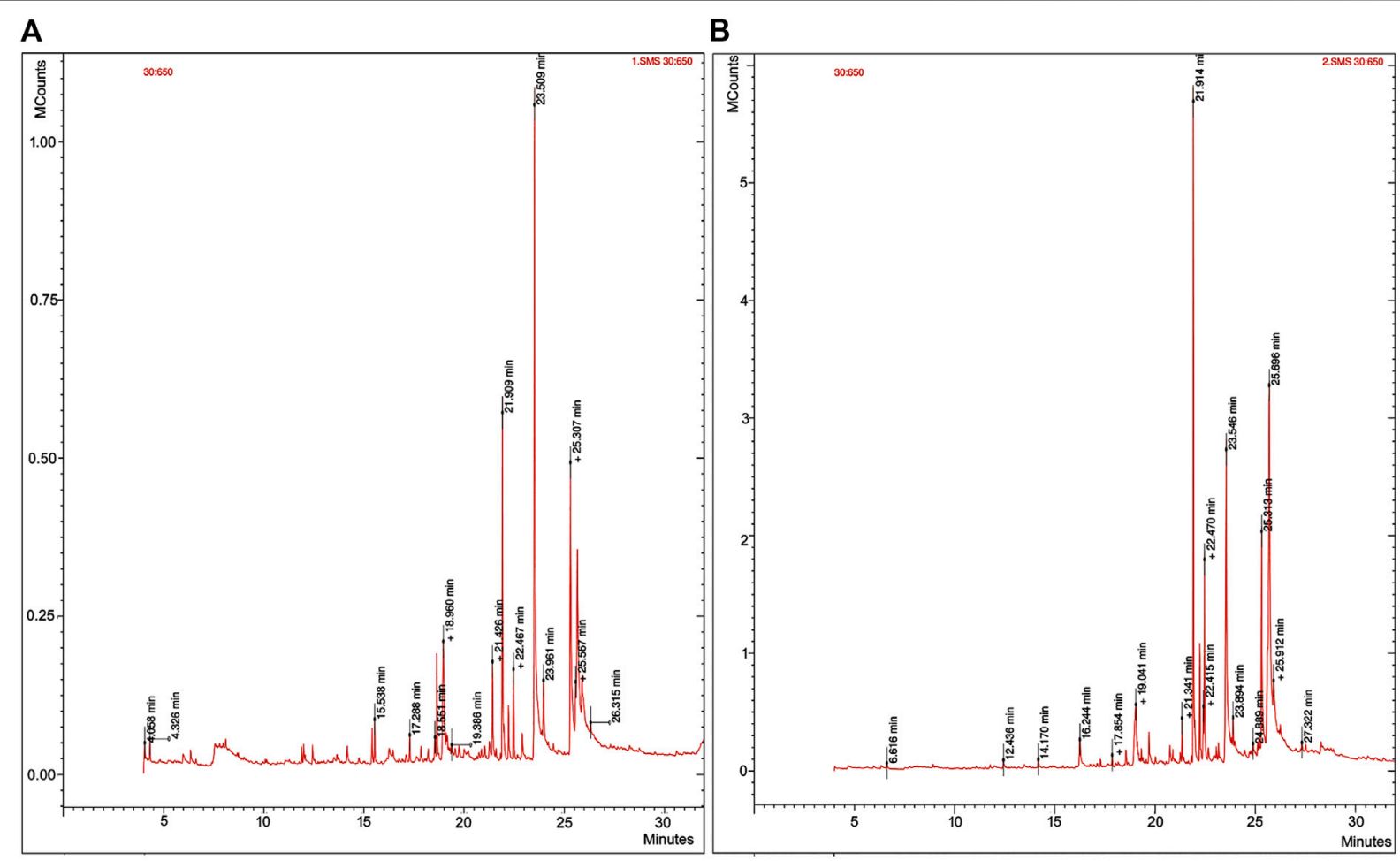

FIGURE 1 | Gas chromatography-mass spectrometry (GC-MS) of Swertia chirayita leaf extracts. (A) Ethanol extract of S. chirayita leaves and (B) methanol extract of S. chirayita leaves.

second time, then observation was done by fluorescence microscopy (Lin et al., 2017). The proportion of cells with green and red fluorescence was determined using bench top fluorescence microscopy Floid $^{\mathrm{TM}}$ Cell Imaging Station, United States) at $\times 40$ magnification with excitation wavelengths of 482/18 (green) and 586/15 (red).

\subsection{Gene Expression by Quantitative Real-Time PCR}

To examine effect of the crude ethanol extract and its ZnO-NPs on the expression level of cancer marker genes (CDK1, E-cadherin, and vimentin) in Caco- 2 cell line, quantitative real-time PCR (qRTPCR) was conducted. GAPDH was used as a housekeeping gene. TRIzol RNA Isolation Reagents (Invitrogen ${ }^{\mathrm{TM}} \mathrm{TRIzol}^{\mathrm{TM}}$ Reagent) was used to extract RNA from treated Caco- 2 cell lines. The process was carried out as per the manufacturer's protocol. cDNA was synthesized from the purified RNA using the Verso cDNA Synthesis Kit (Thermo Fisher Scientific). The quantity of the primers, cDNA, and master mix was prepared according to the procedure given by DyNAmo ColorFlash SYBR Green qPCR Kit (Thermo Fisher Scientific). The Eppendorf Mastercycler Realplex ep gradient RT-PCR instrument was used to perform the qRT-PCR. The PCR setting was as follows: $95^{\circ} \mathrm{C}$ to activate the enzyme for $7 \mathrm{~min}$, followed by 40 cycles of $15 \mathrm{~s}$ at $95^{\circ} \mathrm{C}$ (denaturation) and followed by $30 \mathrm{cycles}$ at $55^{\circ} \mathrm{C}$ at $25 \mathrm{~s}$ and $72^{\circ} \mathrm{C}$ at $25 \mathrm{~s}$ (annealing and synthesis). Finally, a dissociation curve was constructed following the PCR run to validate and justify the results. Primer sequences have been provided in Supplementary Table S3.

\subsection{Statistical Analysis}

GraphPad PRISM 8 software was used to compute all of the data as a mean \pm standard error, and Origin software was also used to generate the graphs. All the tests were carried out three times.

\section{RESULTS}

\subsection{GC-MS Analysis of Bioactive Molecule Extract of S. chirayita Leaves}

GC-MS analysis of ethanol and methanol extracts of S. chirayita leaves recorded a total of 21 and 35 peaks, respectively. The observed results of the leaf extract of $S$. chirayita were in accordance with previous studies (Kumar and Van Staden, 2016; Li et al., 2017). The mass spectra were identified after comparison with the NIST library. The result indicated the presence of several phyto-compounds (Figure 1, Supplementary Tables S1 and 2).

\subsection{Characterization of ZnO Nanoparticles Conjugated With S. chirayita}

During the biosynthesis, the formation of $\mathrm{ZnO}-\mathrm{NPs}$ was visualized. After $3 \mathrm{~h}$ of stirring at a hot plate, the color of the 

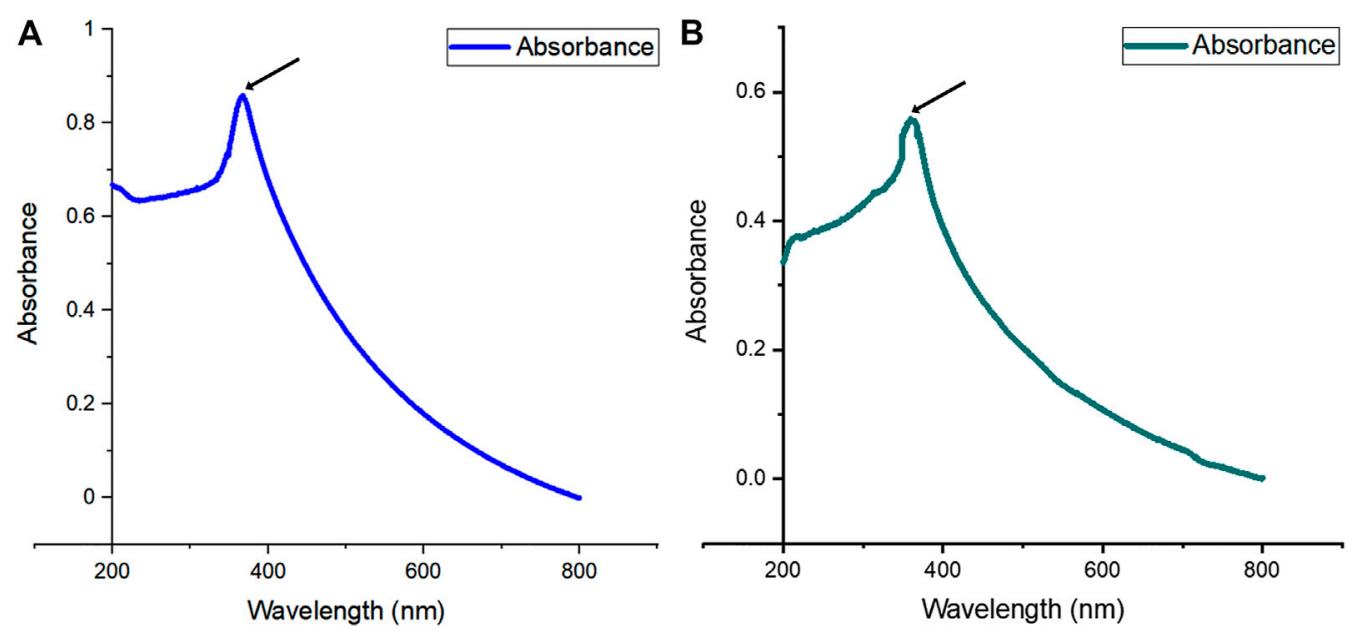

FIGURE 2 | UV-visible (UV-vis) absorption spectra of biogenic ZnO-NPs (from 200 to 800-nm wavelength). (A) Ethanol extract of S. chirayita leaves and (B) methanol extract of $S$. chirayita leaves. Analysis was done using Origin software.

reaction solution gradually changed from white to light yellowish precipitate (Liu et al., 2020), and a change in the color of the solution during synthesis indicated that zinc nitrate had been reduced. These findings were consistent with prior studies of color changes in plant-based $\mathrm{ZnO}-\mathrm{NP}$ production (Santhoshkumar et al., 2017). To verify the presence of the nanoparticles, microscopic and spectroscopic techniques were applied.

\subsubsection{UV-Visible Spectroscopy}

$\mathrm{UV}$-vis spectrum characterization of $\mathrm{ZnO}-\mathrm{NPs}$ was done at room temperature. The analysis was done by scanning the samples at an absorption spectrum range from 200 to $800 \mathrm{~nm}$, and the absorbance peak ( $\lambda \max$ value) was observed at 368 and $364 \mathrm{~nm}$ for ethanol and methanol leaf extracts of S. chirayita, respectively (Figure 2). This is in accordance with previous studies reporting that $\mathrm{ZnO}-\mathrm{NPs}$ showed a maximum absorbance wavelength with in the range of $300-400 \mathrm{~nm}$ (Nethravathi et al., 2015; Jamdagni et al., 2018; Kuruppu et al., 2020; Wijesinghe et al., 2021).

\subsubsection{Dynamic Light Scattering}

DLS was performed to find out the size distribution pattern of $\mathrm{ZnO}-\mathrm{NPs}$. It was diluted in Milli-Q water (1:10) and then passed to a cuvette for analysis. The DLS analysis showed the size distribution of nanoparticles, with an average hydrodynamic size of 285 and $209.9 \mathrm{~nm}$ and a low polydispersity index of 0.274 and 0.185 for $\mathrm{ZnO}-\mathrm{NPs}$ of ethanol and methanol leaf extracts of $S$. chirayita, respectively, indicating good uniformity of ZnO-NPs (Supplementary Figure S1).

\subsubsection{Fourier Transform Infrared Spectroscopy}

FTIR studies were carried out in order to ascertain the phytochemical interactions present between the plant constituents/ functional groups and the nanoparticle. This interaction helped in the reduction and stabilization of the synthesized $\mathrm{ZnO}-\mathrm{NPs}$.
The observed FTIR results of $\mathrm{ZnO}$-NPs were in accordance with previous studies (Awwad et al., 2013; Cheng et al., 2020). The FTIR analysis of synthesized $\mathrm{ZnO}-\mathrm{NPs}$ from the ethanol extract of $S$. chirayita leaf showed wide peaks present at $3,385 \mathrm{~cm}^{-1}$, which reflects the presence of $\mathrm{O}-\mathrm{H}$ stretching vibrations corresponding to an alcohol compound group, whereas 1,507, $1,387,829$, and $719 \mathrm{~cm}^{-1}$ peaks are due to the presence of $\mathrm{N}-\mathrm{O}$ stretching, $\mathrm{C}-\mathrm{H}$ bending, $\mathrm{C}=\mathrm{C}$ bending, and again $\mathrm{C}=\mathrm{C}$ bending, which correspond to nitro compound, aldehyde, alkene, and alkene, respectively (Figure $\mathbf{3 A}$ ). In the same procedure, the analysis of synthesized $\mathrm{ZnO}-\mathrm{NP}$ methanol extract of $S$. chirayita leaves showed wide peaks present at $3,379 \mathrm{~cm}^{-1}$, which reflects the presence of $\mathrm{O}-\mathrm{H}$ stretching that corresponds to an alcohol group, whereas 1,506, 1,379, 835, and $736 \mathrm{~cm}^{-1}$ peaks are due to the presence of $\mathrm{N}-\mathrm{O}$ stretching, $\mathrm{C}-\mathrm{H}$ bending, $\mathrm{C}=\mathrm{C}$ bending, and again $\mathrm{C}=\mathrm{C}$ bending, which correspond to nitro compound, alkane, alkene, and alkene, respectively (Figure 3B).

\subsubsection{X-Ray Diffraction}

The biogenic ZnO-NP's XRD spectrum was analyzed using an $\mathrm{X}$-ray diffraction, resulting in various crystal planes. The crystalline peaks positioned at $(2 \theta)$ peak angles of $31.65^{\circ}$, $34.30^{\circ}, 36.14^{\circ}, 47.42^{\circ}, 56.44^{\circ}, 62.74^{\circ}, 66.20^{\circ}, 67.76^{\circ}, 68.99^{\circ}$, $72.40^{\circ}$, and, $76.77^{\circ}$ corresponding to the reflections from (100), (002), (101), (102), (110), (103), (200), (112), (201), (004), to (202) crystal planes were observed for $\mathrm{ZnO}-\mathrm{NPs}$ from ethanol extract of $S$. chirayita leaves. Meanwhile, for $\mathrm{ZnO}-\mathrm{NPs}$ from methanol extract of $S$. chirayita leaves, crystalline peaks positioned at $(2 \theta)$ peak angles of $31.67^{\circ}, 34.32^{\circ}, 36.14^{\circ}, 47.44^{\circ}$, $56.48^{\circ}, 62.76^{\circ}, 66.18^{\circ}, 67.80^{\circ}, 69.01^{\circ}, 72.42^{\circ}$, and $76.83^{\circ}$ correspond to the reflections from (100), (002), (101), (102), (110), (103), (200), (112), (201), (004), to (202) crystal planes, respectively. The results revealed that $\mathrm{ZnO}$ has a hexagonal structure and that the products have excellent crystallinity. These planes are a good fit for the quartzite $\mathrm{ZnO}$ hexagonal structure, and the same 

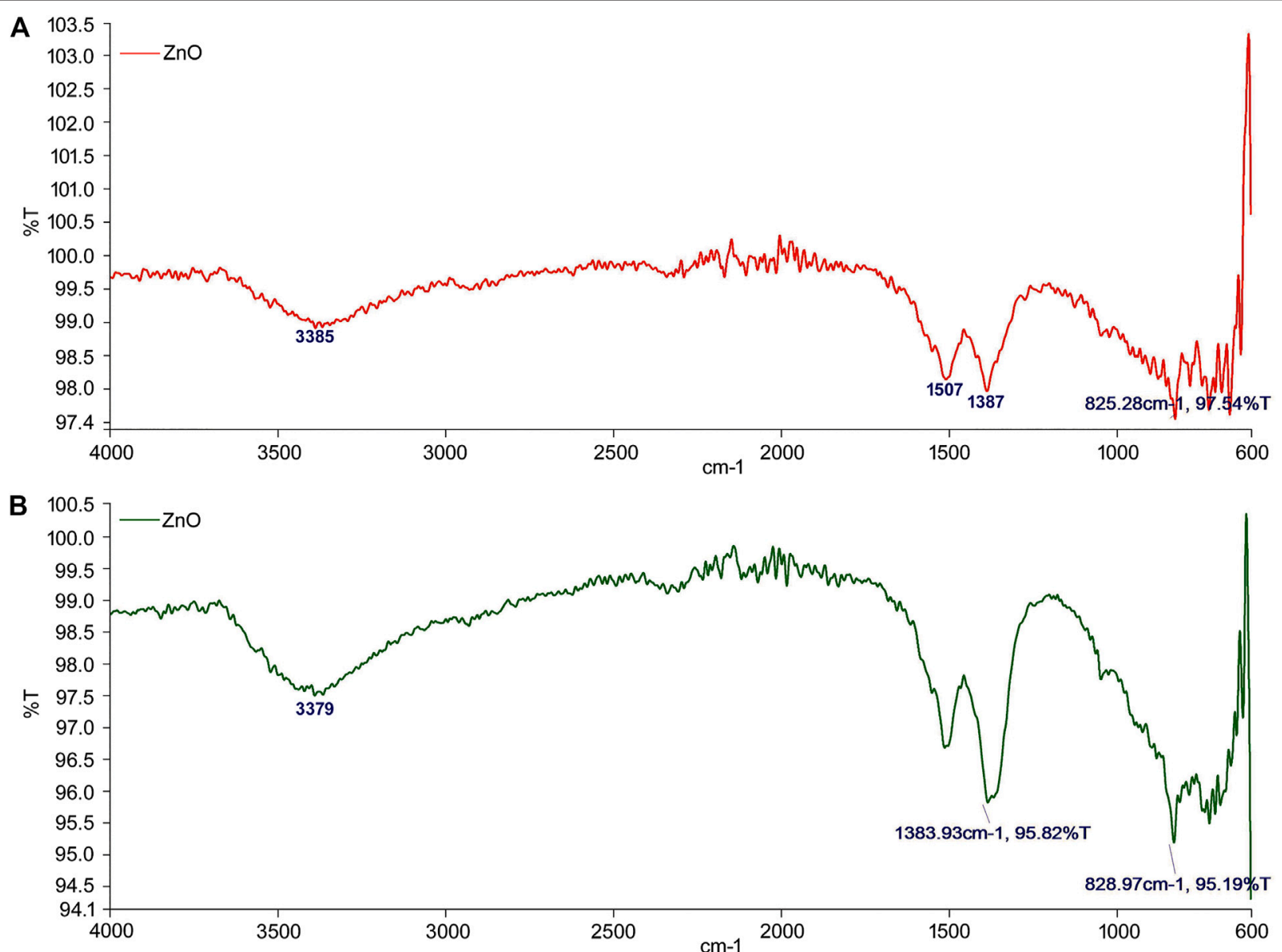

FIGURE 3 | Fourier transform infrared spectroscopy analysis of biogenic ZnO-NPs. (A) Ethanol extract of S. chirayita leaves and (B) methanol extract of S. chirayita leaves.

procedure was also followed by previous studies (Nadia et al., 2019). The ZnO-NPs of both the extracts have been keenly revealed as hexagonal wurtzite with lattice constants $a=b=$ $0.324 \mathrm{~nm}$ and $c=0.521 \mathrm{~nm}$ (JPCDS card number: $36-1451$ ). The average crystalline sizes of the $\mathrm{ZnO}-\mathrm{NPs}$ were 24.67 and $22.95 \mathrm{~nm}$ for ethanol and methanol extracts of $S$. chirayita leaves, respectively. The XRD result illustrated that using different solvents for extraction of $S$. chirayita affected the size of the nanoparticles. It also proves that the produced nanopowder was devoid of contaminants because it lacks any other XRD peaks other than $\mathrm{ZnO}$ peaks. The average size of $\mathrm{ZnO}-\mathrm{NPs}$ was calculated from the highest intensity peaks (101) using the Debye-Scherrer equation (Cao et al., 2011) (Figure 4).

\subsubsection{Scanning Electron Microscopy}

SEM was applied to survey the morphology of $\mathrm{ZnO}$-NPs. SEM images of $\mathrm{ZnO}-\mathrm{NPs}$ synthesized from ethanol and methanol extracts of $S$. chirayita leaves were generated. Topographic view showed that the $\mathrm{ZnO}$-NPs are spherical in shape and are clustered nanocrystallines (Figure 5). Similar outcomes for SEM analysis were disclosed by other studies (Naseer et al., 2020; Pan and Zhong, 2016). The aggregation of $\mathrm{ZnO}-\mathrm{NPs}$ is expected due to the fact that nanoparticles have a larger surface area and adhere to one another more firmly. As a result, environmental variables have a significant impact on the stability of $\mathrm{NP}_{\mathrm{S}}$ and their aggregation (Sundrarajan et al., 2015).

\subsubsection{Transmission Electron Microscopy}

The shape and particle size distribution of $\mathrm{ZnO}$-NPs were further examined using HR-TEM for additional characterization. The spherical form of $\mathrm{ZnO}-\mathrm{NPs}$ in TEM images with an estimated average size of $32.11 \pm 7.659$ and $33.27 \pm 5.851 \mathrm{~nm}$ for synthesized $\mathrm{ZnO}-\mathrm{NPs}$ from ethanol and methanol extracts of $S$. chirayita leaves, respectively (Figure 6), demonstrates that the nanoparticles have a good crystallization.

\subsection{Cytotoxic Activities}

In this study, the cytotoxic effect of plant extracts and synthesized $\mathrm{ZnO}-\mathrm{NPs}$ was evaluated against two colorectal cancer cell lines, HCT-116 and Caco-2, and a control cell line, HEK-293, using MTT assay. MTT assay is considered as a highly accurate and sensitive colorimetric method to check the cell viability after exposure to different therapeutic substances. It is dependent on the ability of succinate dehydrogenase mitochondrial enzyme to 


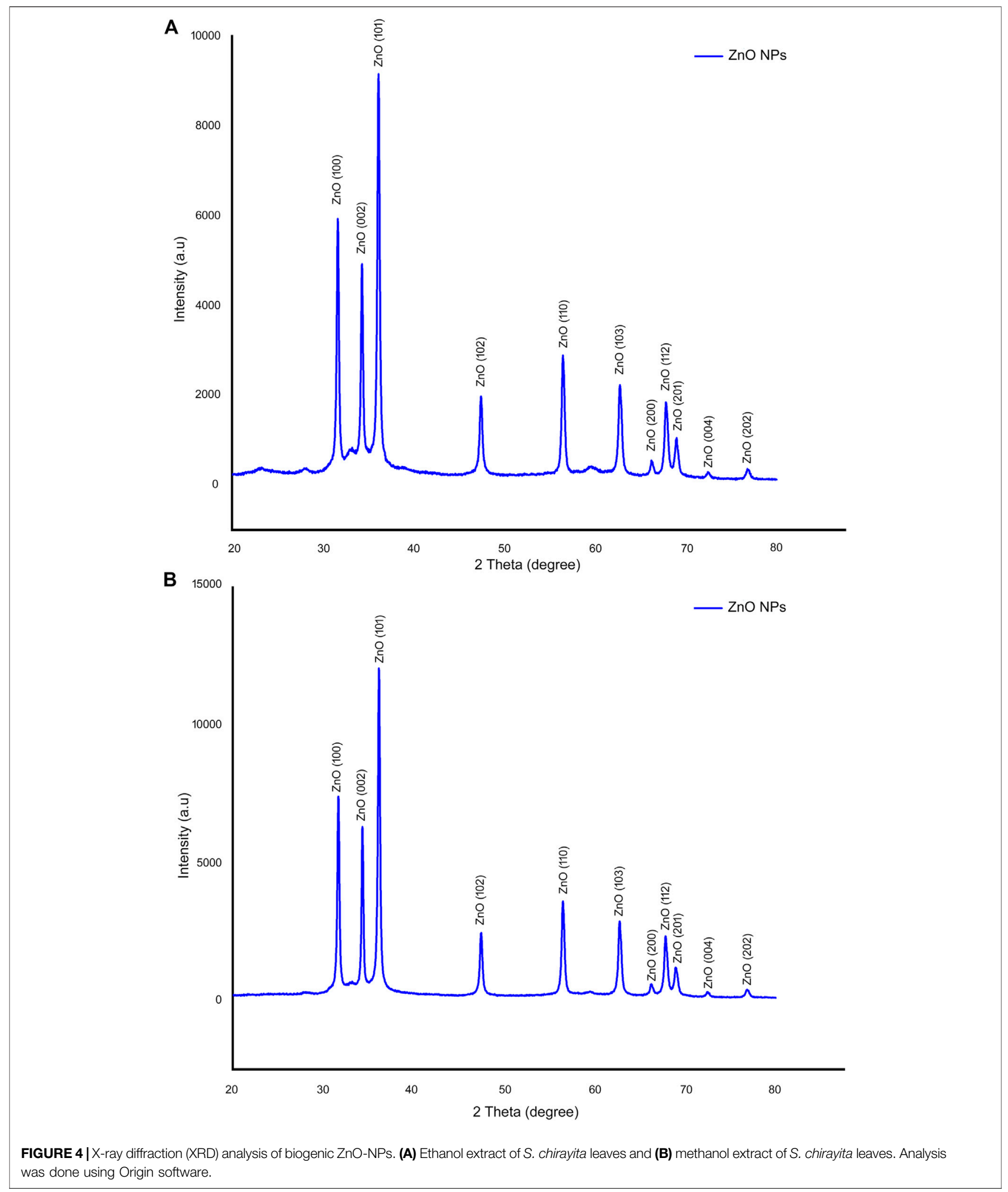

change the tetrazolium yellow dye to formazan crystals, which is directly proportional to the cell viability and assayed as optical density (Rai et al., 2018). Data analysis revealed that the viability of the treated cell lines was dose dependent; as the NP concentration increased, the viability was decreased. This finding is constant with other previous studies (Rajakumar 

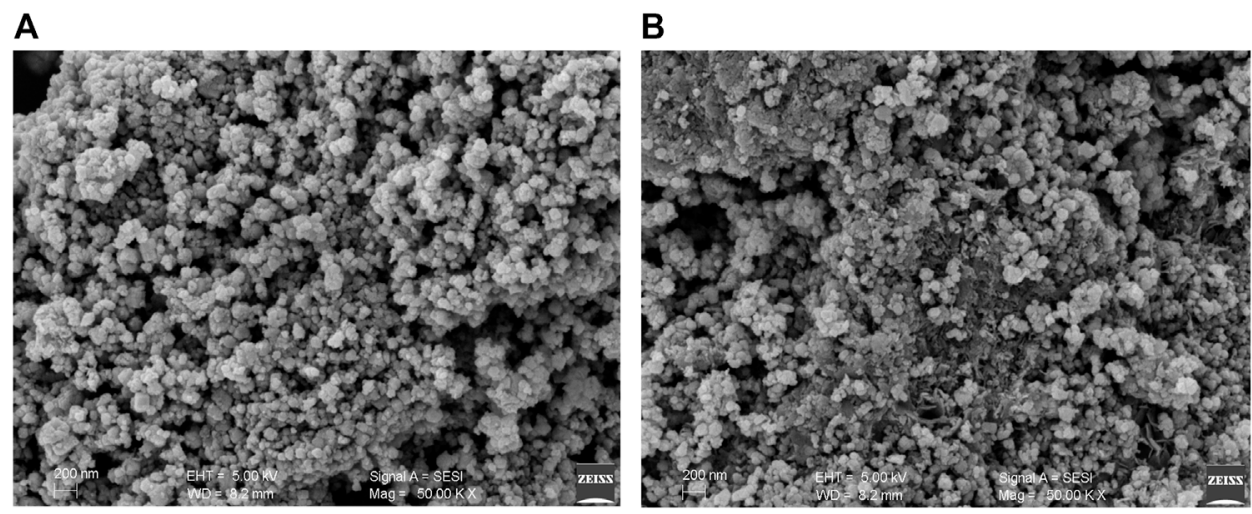

FIGURE 5 | Scanning electron microscopy (SEM) image of biogenic ZnO-NPs. (A) Ethanol extract of S. chirayita leaves and (B) methanol extract of S. chirayita leaves.
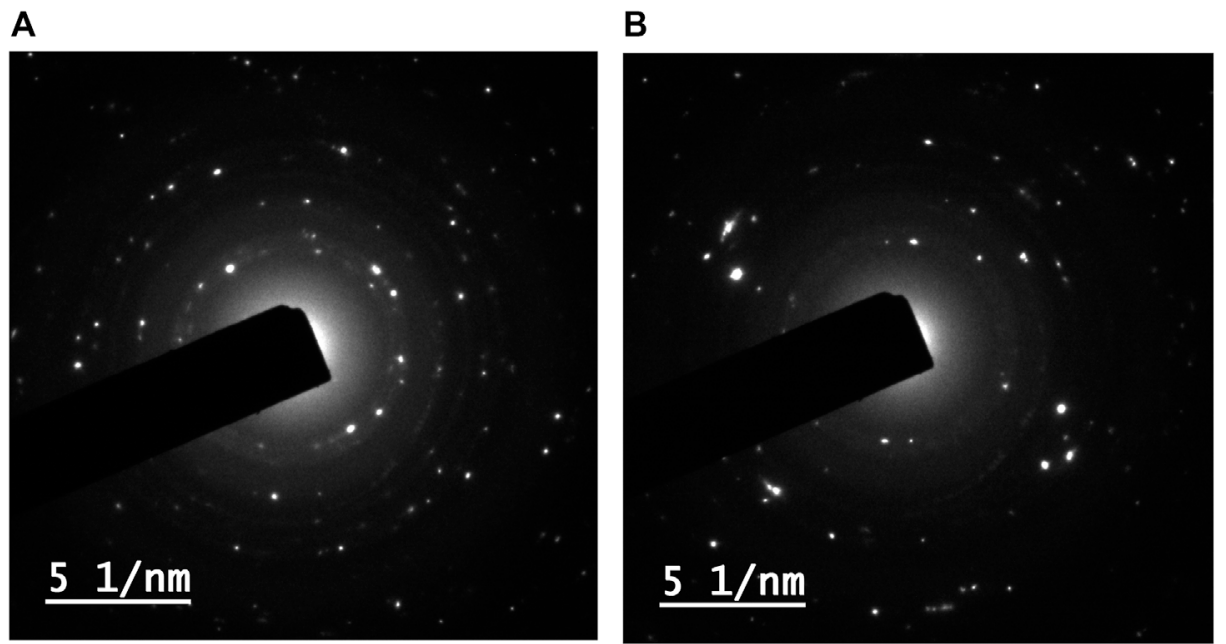

FIGURE 6 | Transmission electron microscopy (TEM) image of biogenic ZnO-NPs. (A) Ethanol extract of S. chirayita leaves and (B) methanol extract of S. chirayita leaves.

et al., 2018). The $\mathrm{IC}_{50}$ values of ethanolic and methanolic extract $\mathrm{ZnO}-\mathrm{NPs}$ for HCT-116, Caco-2, and HEK-293 were $34.356 \pm$ 2.71 and $32.856 \pm 2.99 \mu \mathrm{g} / \mathrm{ml}, 52.15 \pm 8.23$ and $63.1 \pm$ $12.09 \mu \mathrm{g} / \mathrm{ml}$, and $582.84 \pm 5.26$ and $615.35 \pm 4.74 \mu \mathrm{g} / \mathrm{ml}$, respectively (Figures 7A,B). According to these results, it can be inferred that the synthesized nanoparticles from ethanol and methanol crude extracts of $S$. chirayita leaves ( $\mathrm{ZnO}$ SM and $\mathrm{ZnO}$ $\mathrm{SE}$ ) showed cytotoxicity on cancer cells with respect to the crude extracts SM and SE, and the NPs exhibit more cytotoxic potential on cancer cells (HCT-116, and Caco-2) when compared to control cells (HEK-293) (Figures 7A,B).

\subsection{Acridine Orange Staining}

Caco-2 cells treated with SE and ZnO SE of S. chirayita leaves were stained with AO. The result was examined under a fluorescence microscope. The result showed that no significant apoptosis was detected in cells treated with SE of S. chirayita leaves, whereas cells treated with biogenic $\mathrm{ZnO}$ SE of S. chirayita leaves revealed apoptosis (orange/red spots) characterized by chromatin condensation (Figure 8). As reported by various authors, apoptotic signs, plasma membrane blebbing, and crescent-shaped or granular yellow-green AO nuclear staining were observed (Hsin et al., 2008).

\subsection{Gene Expression Analysis of Cancer Markers}

qRT-PCR was used to examine the mRNA levels of some cancer markers such as cell cycle marker (CDK1), epithelial marker (E-cadherin), and mesenchymal marker (vimentin) in Caco-2 cells treated with SE and ZnO SE. Cells treated with ZnO SE had shown a distinct effect on the expression level of CDK1, 
A
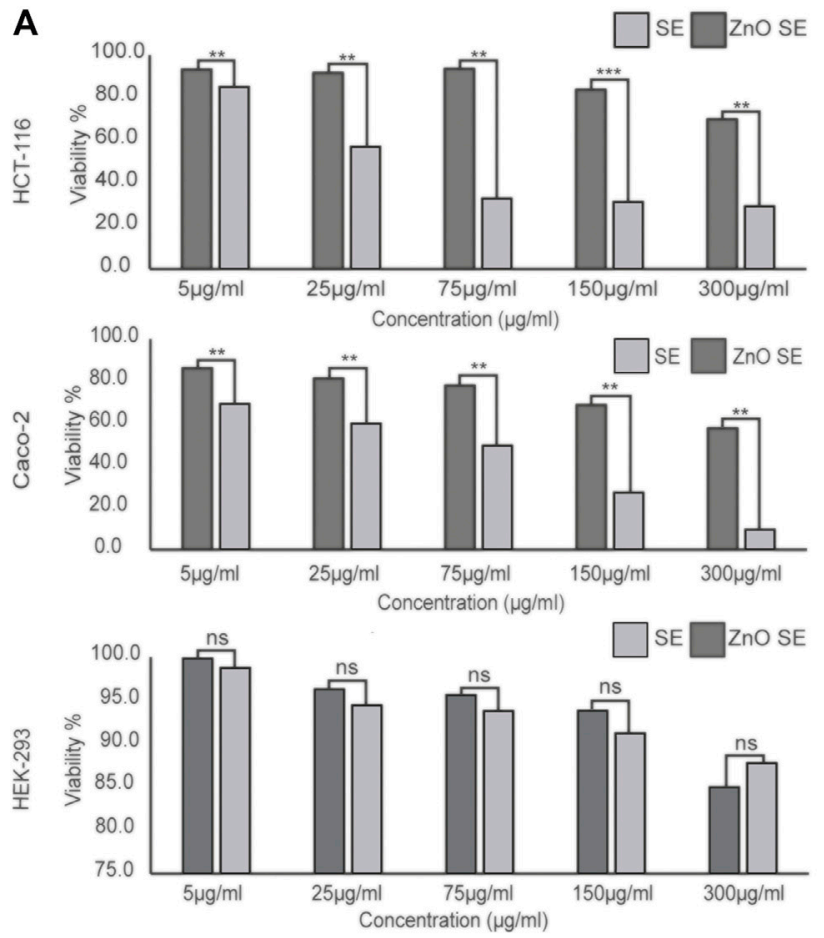
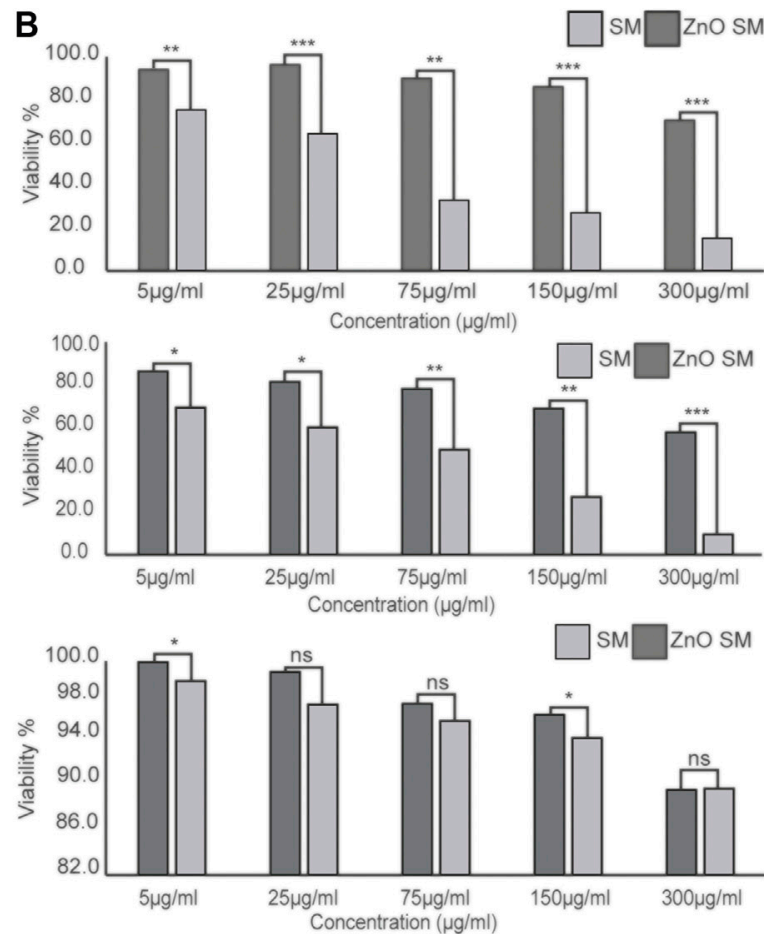

FIGURE 7 | In vitro cytotoxic efficacy of crude extract and green ZnO-NPs synthesized from ethanol (A) and methanol extracts (B) of S. chirayita leaves. Colorectal cancer (CRC) cells (HCT-116 and Caco-2) and control cells (HEK-293) were treated with SE, SM, ZnO SE, and ZnO SM. The results are expressed as cell viability percentage (\%) in comparison between treatments of crude extract and corresponding ZnO-NPs conjugated with the phyto-constituents of the plant. The data represent the mean values \pm SD of three independent experiments performed in triplicate. Statistical values were calculated using ANOVA: single factor. ${ }^{\star} p \leq 0.05,{ }^{\star \star} p \leq 0.01$,

${ }^{\star \star *} p \leq 0.001, \mathrm{nsP}>0.05$. SE, ethanol extract of S. chirayita leaves; SM, methanol extract of S. chirayita leaves; ZnO SE, biogenic ZnO-NPS conjugated with ethanol extract of S. chirayita leaves; ZnO SM, biogenic ZnO-NPs conjugated with methanol extract of S. chirayita leaves.

E-cadherin, and vimentin. The expression level of CDK1 and vimentin was reduced by 0.525 and 0.62 -fold, respectively (with $p$-values 0.013 and 0.041 , respectively), whereas the expression level of E-cadherin increased 2.35-fold ( $p$-value 0.049 ) as compared to the SE treatment (Figure 9).

\section{DISCUSSION}

In this work, $\mathrm{ZnO}-\mathrm{NPs}$ were synthesized using two separate solvents ethanol (80\%) and methanol (90\%) extracts of $S$. chirayita leaves. The phyto-chemical GC-MS analysis of ethanol extract from the leaves of $S$. chirayita revealed that only 21 peaks were observed, but the methanol extract reveals 35 peaks. Related studies had shown that the methanolic extract of $S$. chirayita showed only 15 peaks via HPLC (Wawrosch et al., 2005). Aleem and Kabir (2018) also summarized around 21 chemical constituents of $S$. chirayita and its broad biological activities (Karimzadeh et al., 2020). Active analytes with a high polyphenolic concentration can bind metal ions and help with the capping and reduction of the $\mathrm{ZnO}-\mathrm{NPs}$. UV-visible spectrum displayed a distinct peak around 364 and $368 \mathrm{~nm}$ for ethanol and methanol extract $\mathrm{ZnO}-\mathrm{NPs}$, respectively. There have been no more significant peak shifts observed, which is particular for $\mathrm{ZnO}-\mathrm{NPs}$. This is in accordance with previous studies reporting that $\mathrm{ZnO}-\mathrm{NPs}$ show a maximum absorbance wavelength within the range of 300-400 $\mathrm{nm}$ (Nethravathi et al., 2015; Jamdagni et al., 2018; Kuruppu et al., 2020; Wijesinghe et al., 2021).

The synthesis method was found to be efficient, as evidenced by the generation of single-crystalline $\mathrm{ZnO}$-NPs with a hexagonal wurtzite structure, as determined by XRD. The average crystallite size of the nanoparticles was 24.67 and $22.95 \mathrm{~nm}$ for $\mathrm{ZnO}-\mathrm{NPs}$ synthesized by ethanol and methanol solvents, respectively, exhibiting spherical-like structures. The ZnO-NPs' XRD spectrum was detected using X-ray diffraction, resulting in various crystal planes. The crystalline peaks positioned at $(2 \theta)$ angles of $31.65^{\circ}, 34.30^{\circ}, 36.14^{\circ}, 47.42^{\circ}, 56.44^{\circ}, 62.74^{\circ}, 66.20^{\circ}, 67.76^{\circ}$, $68.99^{\circ}, 72.40^{\circ}$, and $76.77^{\circ}$ corresponding to the reflections from (100), (002), (101), (102), (110), (103), (200), (112), (201), (004), to (202) crystal planes were observed for $\mathrm{ZnO}-\mathrm{NPs}$ from ethanol extract of $S$. chirayita leaves. Meanwhile, for $\mathrm{ZnO}-\mathrm{NPs}$ from methanol extract of $S$. chirayita leaves, crystalline peaks positioned at $(2 \theta)$ peak angles of $31.67^{\circ}, 34.32^{\circ}, 36.14^{\circ}, 47.44^{\circ}$, $56.48^{\circ}, 62.76^{\circ}, 66.18^{\circ}, 67.80^{\circ}, 69.01^{\circ}, 72.42^{\circ}$, and $76.83^{\circ}$ correspond to the reflections from (100), (002), (101), (102), (110), (103), (200), (112), (201), (004), to (202) crystal planes, respectively. The result showed that the synthesized $\mathrm{ZnO}-\mathrm{NPs}$ have a hexagonal form and have excellent crystallinity. These planes fit well with previous studies (Bhatte et al., 2012; Nadia et al., 2019; Naseer et al., 2020) as well as JCPDS card no. 36-1451. 


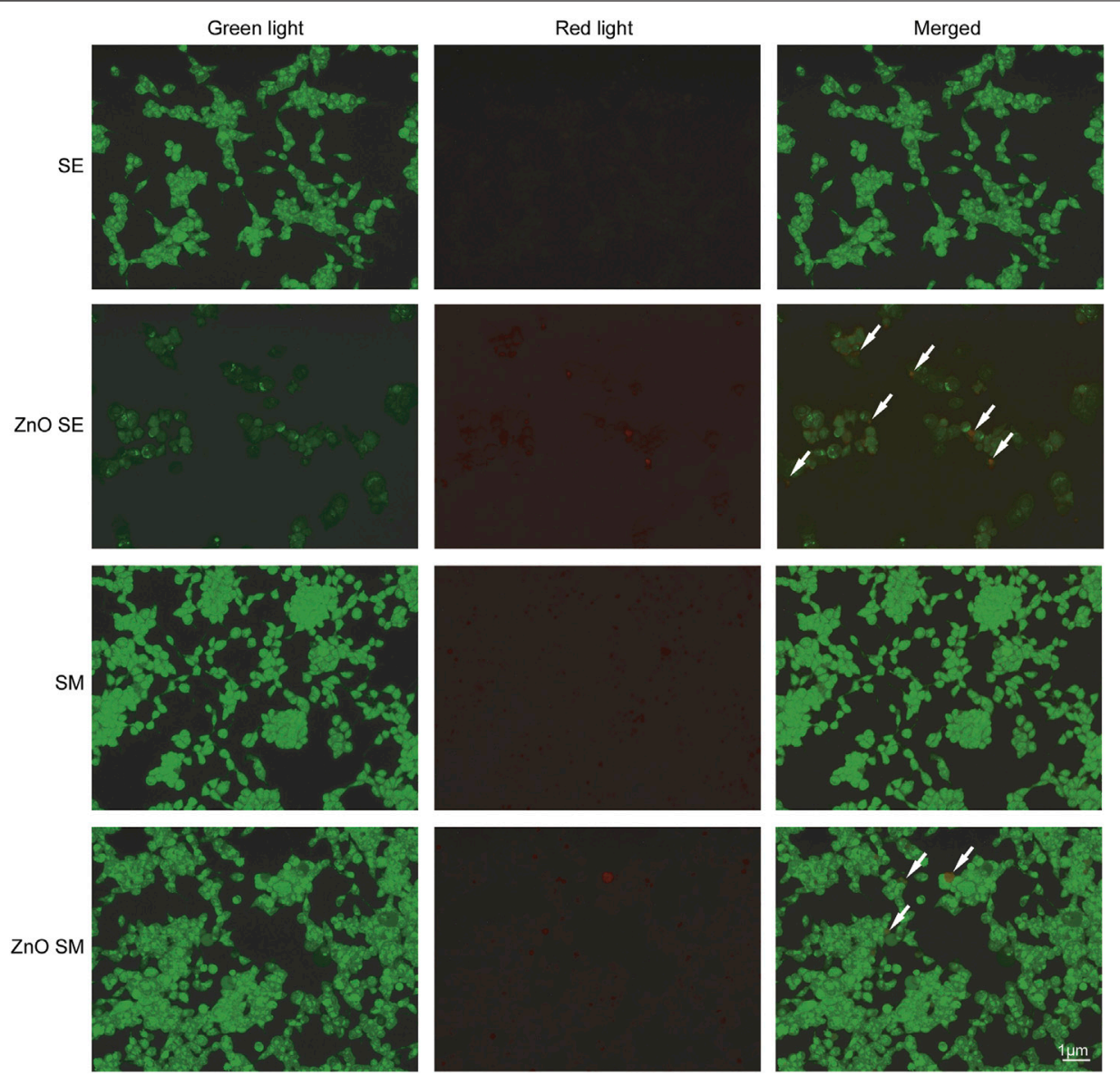

FIGURE 8| Acridine orange (AO) staining. Acridine orange staining of Caco-2 cells to detect apoptosis. Live cells are uniformly green, whereas apoptotic cells are stained orange-red due to chromatin condensation and loss of membrane integrity. Pictures were taken at magnification of $\times 40$.

FTIR spectroscopy was used to determine the functional groups in the production of $\mathrm{ZnO}-\mathrm{NPs}$. The wide peaks at 3,385 and $3,379 \mathrm{~cm}^{-1}$ reflect the presence of $\mathrm{O}-\mathrm{H}$ stretching corresponding to an alcohol compound group in the $\mathrm{ZnO}-\mathrm{NPs}$ from ethanol and methanol extracts of $S$. chirayita leaves, respectively. These results are inconsistent with previous studies (Cheng et al., 2020). According to the FTIR analysis, the synthesized $\mathrm{ZnO}$-NPs are conjugated with different phytochemicals, which act as capping and stabilizing agents for the synthesis of $\mathrm{ZnO}-\mathrm{NPs}$.

For the ZnO-NPs synthesized from ethanol and methanol extracts of $S$. chirayita leaves, DLS analysis revealed a size distribution of particles with an average hydrodynamic size of 285 and $209.9 \mathrm{~nm}$, respectively. Similar previous studies showed that the average size from the DLS analysis was larger than that from XRD and TEM, and this happened due to the polydisperse nature of NPs (Jamdagni et al., 2018). TEM analysis showed that the major series of particle size was between 19.8 and $23.4 \mathrm{~nm}$, and SEM analysis showed that the $\mathrm{ZnO}-\mathrm{NPs}$ are spherical in shape and are clusters of nanocrystallites, which is supported by previous similar findings too (Naseer et al., 2020; Pan and Zhong, 2016).
Data analysis for cytotoxicity effect revealed that the viability of treated cell lines was dose dependent; as the concentration of $\mathrm{ZnO}-\mathrm{NPs}$ increased, the viability decreased (Sanaeimehr et al., 2018). Cytotoxicity activities of ethanol and methanol crude extracts of S. chirayita leaves (SE and SM) and synthesized nanoparticles ( $\mathrm{ZnO} \mathrm{SE}$ and $\mathrm{ZnO}$ SM) were analyzed by MTT assay. In this study, we showed that the biogenic $\mathrm{ZnO}-\mathrm{NPs}$ have cytotoxic activities against colorectal cancer cell lines (HCT-116 and Caco-2) but insignificant activities against the control cell line (HEK293). Both the $\mathrm{ZnO} \mathrm{SE}$ and $\mathrm{ZnO}$ SM showed significant cytotoxic activities in a concentration-dependent manner $(5-300 \mu \mathrm{g} / \mathrm{ml})$. Our findings showed that $\mathrm{ZnO}-\mathrm{NPs}$ have more cytotoxic effects compared to the corresponding crude extract of $S$. chirayita leaves. The $\mathrm{IC}_{50}$ values of ethanolic and methanolic extract ZnO-NPs for HCT-116, Caco-2, and HEK-293 were $34.356 \pm 2.71$ and $32.856 \pm$ $2.99 \mu \mathrm{g} / \mathrm{ml}, 52.15 \pm 8.23$ and $63.1 \pm 12.09 \mu \mathrm{g} / \mathrm{ml}$, and $582.84 \pm 5.26$ and $615.35 \pm 4.74 \mu \mathrm{g} / \mathrm{ml}$, respectively. Similarly, other studies also showed that biologically synthesized ZnO-NPs had anticancer activities in HCT-116 cell lines (Majeed et al., 2019). It was shown that Caco-2 cell 
qRT-PCR result analysis of mRNA expression level of Zinc oxide nanoparticle of ethanol extract

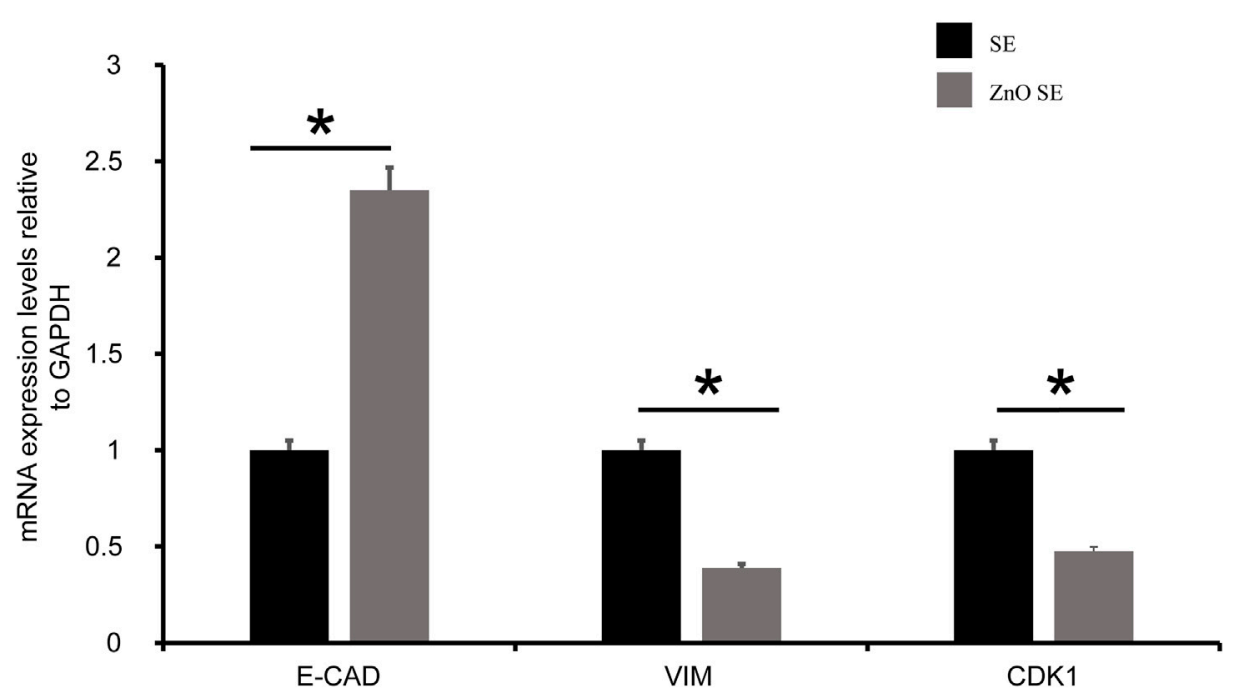

FIGURE 9| Quantitative real-time PCR (qRT-PCR) analysis. The expression level of CDK1 and vimentin in Caco- 2 cell lines treated with ZnO SE reduced by 0.525 and 0.62 -fold, respectively (with $p$-Value $=0.013$ and 0.041 ), whereas the expression level of E-cadherin increased 2.35 -fold $(p$-Value $=0.049$ ) as compared to cells treated with SE.

lines treated with green-synthesized $\mathrm{ZnO}-\mathrm{NPs}$ displayed cytotoxic activities with an $\mathrm{IC}_{50}$ value of $9.95 \mathrm{ppm}$, after $48 \mathrm{~h}$ of treatment (El-Belely et al., 2021). Similarly, Kang et al. (2013) showed $15.55 \pm 1.19 \mu \mathrm{g} / \mathrm{ml}, 22.84 \pm 1.36 \mu \mathrm{g} / \mathrm{ml}$, and $18.57 \pm 1.27 \mu \mathrm{g} / \mathrm{ml} \mathrm{IC} \mathrm{I}_{50}$ values for three different sizes of green-synthesized $\mathrm{ZnO}-\mathrm{NPs}-26,62$, and $90 \mathrm{~nm}$, respectively. Green-synthesized $\mathrm{ZnO}-\mathrm{NPs}$ from D. tortuosa aqueous extract showed a profound selective cytotoxic effect on the Caco-2 and A549 cancer cell lines (Selim et al., 2020). Sanaeimehr et al. (2018) showed that green-synthesized zinc oxide nanoparticles using Sargassum muticum algae extract have a cytotoxic activity on HepG2 cell lines at an $\mathrm{IC}_{50}$ value of $150 \mu \mathrm{g} / \mathrm{ml}$ after $48 \mathrm{~h}$ of exposure time. Biogenic $\mathrm{ZnO}-\mathrm{NPs}$ were found to have a cytotoxic effect against both HCT-116 and Caco-2 cancer cell lines but a reduced cytotoxic activity in normal human HEK-293 cell lines. The same result was demonstrated in various studies (Wahab et al., 2011; Shandiz et al., 2021).

AO staining showed that no significant apoptosis was detected in cells treated with SE, whereas cells treated with $\mathrm{ZnO}$ SE revealed apoptotic signs, plasma membrane blebbing, and crescent-shaped or granular yellow-green AO nuclear staining. Earlier, it has been shown that ZnO-NPs induced apoptosis as well as oxidative stress in vitro and in vivo (Verma et al., 2017; Das et al., 2019). This study is in line with the previous research done by Kang et al. (2013). In their paper, they demonstrated that AO analysis of Caco-2 cells treated with different doses of $\mathrm{ZnO}-\mathrm{NPs}$ showed a significant reduction in viable cells and an increase in early apoptotic cells, late apoptotic cells, and necrotic cells (Kang et al., 2013).

qRT-PCR analysis of Caco-2 cell lines treated with $\mathrm{ZnO}$ SE showed a significantly reduced expression level of CDK1 and vimentin by 0.525 and 0.62 -fold, respectively, whereas the expression level of E-cadherin increased 2.35-fold as compared to SE-treated cells. Cells treated with biogenic $\mathrm{ZnO}-\mathrm{NPs}$ showed a reduced level of the expression of oncogene cancer markers, revealing its anticancer activities (Liu et al., 2013; Zhu et al., 2015).

A study done by Saha et al. (2004) showed that significant anticancer activities were observed after both the crude and purified S. chirayita extracts significantly inhibited cell proliferation and induced apoptosis. In summary, it could be concluded that the solvents we used for the extraction of plant phyto-constituents affect the application of the synthesized $\mathrm{ZnO}-\mathrm{NPs}$ on cells. Biogenic $\mathrm{ZnO}-\mathrm{NPs}$ are eco-friendly, costeffective, and less toxic. This offers promising alternatives to current chemotherapy, but further biomolecular tests and mechanism-of-action and in vivo studies should be evaluated for further use.

\section{CONCLUSION}

In summary, the findings show that the biogenic synthesized $\mathrm{ZnO}-\mathrm{NPs}$ from the extract of $S$. chirayita leaves are pure-standard NPs and spherical in shape, with anticancer activities. These were proven by characterization of the biogenic $\mathrm{ZnO}$-NPs through UV-vis, FTIR, XRD, SEM, and TEM. X-ray diffraction analysis ratified the formation of zinc oxide hexagonal wurtzite structure with spherical shape. Their anticancer activities were also proved by performing the cytotoxic assay, AO staining, and qRT-PCR. The synthesized nanoparticles have the potential to become alternative anti-cancer treatments, but further in vitro and in vivo studies are needed. 


\section{DATA AVAILABILITY STATEMENT}

The original contributions presented in the study are included in the article/Supplementary Material; further inquiries can be directed to the corresponding author.

\section{AUTHOR CONTRIBUTIONS}

$\mathrm{HB}$ and AS made contributions in data generation, interpretation and analysis, manuscript writing, and final approval. MK made contributions in data generation and drafting the work. RC drafted the figures, analysis, edited the manuscript, and final approval. KL conducted the literature review, and drafted the work. JP critically reviewed the manuscript. BM conducted the literature review and assisted with the experiments. AM reviewed and edited the manuscript. SP made contributions in the conceptualization, supervision, and review and editing. All authors contributed to the article and approved the submitted version.

\section{REFERENCES}

Ahmad, A., Tiwari, R. K., Almeleebia, T. M., Al Fayi, M. S., Alshahrani, M. Y., Ahmad, I., et al. (2021). Swertia Chirayita Suppresses the Growth of Non-small Cell Lung Cancer A549 Cells and Concomitantly Induces Apoptosis via Downregulation of JAK1/STAT3 Pathway. Saudi J. Biol. Sci. 28 (11), 6279-6288. doi:10.1016/j.sjbs.2021.06.085

Aleem, A., and Kabir, H. (2018). Review on Swertia Chirata as Traditional Uses to its Pyhtochemistry and Phrmacological Activity. J. Drug Deliv. Ther. 8 (5-s), 73-78. doi:10.22270/jddt.v8i5-s.1957

Awwad, A. M., Salem, N. M., and Abdeen, A. O. (2013). Green Synthesis of Silver Nanoparticles Using Carob Leaf Extract and its Antibacterial Activity. Int. J. Ind. Chem. 4 (1), 29-36. doi:10.1186/2228-5547-4-29

Banerjee, A., Pathak, S., Subramanium, V. D., G., D., Murugesan, R., and Verma, R. S. (2017). Strategies for Targeted Drug Delivery in Treatment of colon Cancer: Current Trends and Future Perspectives. Drug Discov. Today 22 (8), 1224-1232. doi:10.1016/j.drudis.2017.05.006

Bhatte, K. D., Sawant, D. N., Pinjari, D. V., Pandit, A. B., and Bhanage, B. M. (2012). One Pot green Synthesis of Nano Sized Zinc Oxide by Sonochemical Method. Mater. Lett. 77, 93-95. doi:10.1016/j.matlet.2012.03.012

Bray, F., Ferlay, J., Soerjomataram, I., Siegel, R. L., Torre, L. A., and Jemal, A. (2018). Global Cancer Statistics 2018: GLOBOCAN Estimates of Incidence and Mortality Worldwide for 36 Cancers in 185 Countries. CA: a Cancer J. clinicians 68 (6), 394-424. doi:10.3322/caac.21492

Cao, Y., Liu, B., Huang, R., Xia, Z., and Ge, S. (2011). Flash Synthesis of Flower-like $\mathrm{ZnO}$ Nanostructures by Microwave-Induced Combustion Process. Mater. Lett. 65 (2), 160-163. doi:10.1016/j.matlet.2010.09.072

Cheng, J., Wang, X., Qiu, L., Li, Y., Marraiki, N., Elgorban, A. M., et al. (2020). Green Synthesized Zinc Oxide Nanoparticles Regulates the Apoptotic Expression in Bone Cancer Cells MG-63 Cells. J. Photochem. Photobiol. B: Biol. 202, 111644. doi:10.1016/j.jphotobiol.2019.111644

Das, B. K., Verma, S. K., Das, T., Panda, P. K., Parashar, K., Suar, M., et al. (2019). Altered Electrical Properties with Controlled Copper Doping in $\mathrm{ZnO}$ Nanoparticles Infers Their Cytotoxicity in Macrophages by ROS Induction and Apoptosis. Chemico-biological interactions 297, 141-154. doi:10.1016/j.cbi.2018.11.004

Dekker, E., Tanis, P. J., Vleugels, J. L. A., Kasi, P. M., and Wallace, M. B. (2019). Colorectal Cancer. The Lancet 394 (10207), 1467-1480. doi:10.1016/S01406736(19)32319-0

Divya, M. J., Sowmia, C., Joona, K., and Dhanya, K. P. (2013). Synthesis of Zinc Oxide Nanoparticle from Hibiscus Rosa-Sinensis Leaf Extract and Investigation of its Antimicrobial Activity. Res. J. Pharm. Biol. Chem. 4 (2), 1137-1142. doi:10.7897/2230-8407.04541

\section{FUNDING}

HM acknowledges the Ethiopian Ministry of Education, Betre Science Scholarship (19000164), and AS acknowledges the CSIR for research fellowship support under CSIR-NET-SRF program (09/1035 (0010)/2017-EMR-1).

\section{ACKNOWLEDGMENTS}

We are thankful to KIIT School of Biotechnology, KIIT Deemed to be University.

\section{SUPPLEMENTARY MATERIAL}

The Supplementary Material for this article can be found online at: https://www.frontiersin.org/articles/10.3389/fbioe.2021.788527/ full\#supplementary-material

El-Belely, E. F., Farag, M. M. S., Said, H. A., Amin, A. S., Azab, E., Gobouri, A. A., et al. (2021). Green Synthesis of Zinc Oxide Nanoparticles (ZnO-NPs) Using Arthrospira Platensis (Class: Cyanophyceae) and Evaluation of Their Biomedical Activities. Nanomaterials 11 (1), 95. doi:10.3390/nano11010095

Gan, P. P., and Li, S. F. Y. (2012). Potential of Plant as a Biological Factory to Synthesize Gold and Silver Nanoparticles and Their Applications. Rev. Environ. Sci. Biotechnol. 11 (2), 169-206. doi:10.1007/s11157-012-9278-7

Hsin, Y.-H., Chen, C.-F., Huang, S., Shih, T.-S., Lai, P.-S., and Chueh, P. J. (2008). The Apoptotic Effect of Nanosilver Is Mediated by a ROS- and JNK-dependent Mechanism Involving the Mitochondrial Pathway in NIH3T3 Cells. Toxicol. Lett. 179 (3), 130-139. doi:10.1016/j.toxlet.2008.04.015

Hussain, M. K., Saquib, M., and Khan, M. F. (2019). “Techniques for Extraction, Isolation, and Standardization of Bio-active Compounds from Medicinal Plants" in Natural Bio-Active Compounds. Singapore: Springer, 179-200.

Hwang, T. I., Liao, T.-L., Lin, J.-F., Lin, Y.-C., Lee, S.-Y., Lai, Y.-C., et al. (2011). Low-dose Testosterone Treatment Decreases Oxidative Damage in TM3 Leydig Cells. Asian J. Androl. 13 (3), 432-437. doi:10.1038/aja.2010.159

Jamdagni, P., Khatri, P., and Rana, J. S. (2018). Green Synthesis of Zinc Oxide Nanoparticles Using Flower Extract of Nyctanthes Arbor-Tristis and Their Antifungal Activity. J. King Saud Univ. - Sci. 30 (2), 168-175. doi:10.1016/j.jksus.2016.10.002

Jeught, K. V. d., Xu, H.-C., Li, Y.-J., Lu, X.-B., and Ji, G. (2018). Drug Resistance and New Therapies in Colorectal Cancer. Wjg 24 (34), 3834-3848. doi:10.3748/ wjg.v24.i34.3834

Kang, T., Guan, R., Chen, X., Song, Y., Jiang, H., and Zhao, J. (2013). In Vitro toxicity of Different-Sized ZnO Nanoparticles in Caco-2 Cells. Nanoscale Res. Lett. 8 (1), 496-498. doi:10.1186/1556-276X-8-496

Karimzadeh, M. R., Soltanian, S., Sheikhbahaei, M., and Mohamadi, N. (2020). Characterization and Biological Activities of Synthesized Zinc Oxide Nanoparticles Using the Extract of Acantholimon Serotinum. Green. Process. Synth. 9 (1), 722-733. doi:10.1515/gps-2020-0058

Khalil, A. T., Ovais, M., Ullah, I., Ali, M., Shinwari, Z. K., Khamlich, S., et al. (2017). Sageretia Thea (Osbeck.) Mediated Synthesis of Zinc Oxide Nanoparticles and its Biological Applications. Nanomedicine 12 (15), 1767-1789. doi:10.2217/nnm-2017-0124

Khanal, S., Shakya, N., Nepal, N., and Pant, D. (2014). Swertia Chirayita: the Himalayan Herb. Int. J. Appl. Sci. Biotechnol. 2 (4), 389-392. doi:10.3126/ijasbt.v2i4.11281

Kumar, V., and Van Staden, J. (2016). A Review of Swertia Chirayita (Gentianaceae) as a Traditional Medicinal Plant. Front. Pharmacol. 6, 308. doi:10.3389/fphar.2015.00308

Kumari, S., kumari, P., Panda, P. K., Pramanik, N., Verma, S. K., and Mallick, M. A. (2019). Molecular Aspect of Phytofabrication of Gold Nanoparticle from Andrographis Peniculata Photosystem II and Their In Vivo Biological Effect on Embryonic Zebrafish (Danio rerio). Environ. Nanotechnology, Monit. Manag. 11, 100201. doi:10.1016/j.enmm.2018.100201 
Kuruppu, K. A. S. S., Perera, K. M. K. G., Chamara, A. M. R., and Thiripuranathar, G. (2020). Flower Shaped ZnO-NPs; Phytofabrication, Photocatalytic, Fluorescence Quenching, and Photoluminescence Activities. Nano Express 1 (2), 020020. doi:10.1088/2632-959x/aba862

Li, J., Zhao, Y.-L., Huang, H.-Y., and Wang, Y.-Z. (2017). Phytochemistry and Pharmacological Activities of the Genus Swertia (Gentianaceae): a Review. Am. J. Chin. Med. 45 (04), 667-736. doi:10.1142/s0192415x17500380

Lin, Y. C., Lin, J. F., Tsai, T. F., Chen, H. E., Chou, K. Y., Yang, S. C., et al. (2017). Acridine orange Exhibits Photodamage in Human Bladder Cancer Cells under Blue Light Exposure. Sci. Rep. 7 (1), 14103-14111. doi:10.1038/s41598-017-13904-0

Liu, Z. Y., Shen, C. L., Lou, Q., Zhao, W. B., Wei, Y. J., Liu, K. K., et al. (2020). Efficient Chemiluminescent ZnO Nanoparticles For Cellular imaging. J. Lumin. 221, 117111.

Liu, Y., Wang, W., Fang, B., Ma, F., Zheng, Q., Deng, P., et al. (2013). Anti-tumor Effect of Germacrone on Human Hepatoma Cell Lines through Inducing G2/M Cell Cycle Arrest and Promoting Apoptosis. Eur. J. Pharmacol. 698 (1-3), 95-102. doi:10.1016/j.ejphar.2012.10.013

Majeed, S., Danish, M., Ismail, M. H. B., Ansari, M. T., and Ibrahim, M. N. M. (2019). Anticancer and Apoptotic Activity of Biologically Synthesized Zinc Oxide Nanoparticles against Human colon Cancer HCT-116 Cell Line- In Vitro Study. Sustain. Chem. Pharm. 14, 100179. doi:10.1016/j.scp.2019.100179

Mishra, P. K., Mishra, H., Ekielski, A., Talegaonkar, S., and Vaidya, B. (2017). Zinc Oxide Nanoparticles: a Promising Nanomaterial for Biomedical Applications. Drug Discov. Today 22 (12), 1825-1834. doi:10.1016/j.drudis.2017.08.006

Mosmann, T. (1983). Rapid Colorimetric Assay for Cellular Growth and Survival: Application to Proliferation and Cytotoxicity Assays. J. Immunol. Methods 65 (1-2), 55-63. doi:10.1016/0022-1759(83)90303-4

Nadia, D., Gali, L., Arbah, R., and Abdessamed, A. (2019). Of Zno Nanoparticles Using phoenix Dactylifera. L Leaf Extract: Effect of Zinc Acetate Concentration on the Type of Product. Algeria: Wulfenia.

Naseer, M., Aslam, U., Khalid, B., and Chen, B. (2020). Green Route to Synthesize Zinc Oxide Nanoparticles Using Leaf Extracts of Cassia Fistula and Melia Azadarach and Their Antibacterial Potential. Sci. Rep. 10 (1), 9055-9110. doi:10.1038/s41598-020-65949-3

Nethravathi, P. C., Shruthi, G. S., Suresh, D., Udayabhanu, H., Nagabhushana, H., and Sharma, S. C. (2015). Garcinia Xanthochymus Mediated green Synthesis of $\mathrm{ZnO}$ Nanoparticles: Photoluminescence, Photocatalytic and Antioxidant Activity Studies. Ceramics Int. 41 (7), 8680-8687. doi:10.1016/j.ceramint.2015.03.084

Pan, K., and Zhong, Q. (2016). Organic Nanoparticles in Foods: Fabrication, Characterization, and Utilization. Annu. Rev. Food Sci. Technol. 7, 245-266.

P. Singh, R., K. Shukla, V., S. Yadav, R., K. Sharma, P., K. Singh, P., and C. Pandey, A. (2011). Biological Approach of Zinc Oxide Nanoparticles Formation and its Characterization. Adv. Mater. Lett. 2 (4), 313-317. doi:10.5185/amlett.indias.204

Rai, Y., Pathak, R., Kumari, N., Sah, D. K., Pandey, S., Kalra, N., et al. (2018). Mitochondrial Biogenesis and Metabolic Hyperactivation Limits the Application of MTT Assay in the Estimation of Radiation Induced Growth Inhibition. Sci. Rep. 8 (1), 1-15. doi:10.1038/s41598-018-19930-w

Rajakumar, G., Thiruvengadam, M., Mydhili, G., Gomathi, T., and Chung, I.-M. (2018). Green Approach for Synthesis of Zinc Oxide Nanoparticles from Andrographis Paniculata Leaf Extract and Evaluation of Their Antioxidant, Anti-diabetic, and Anti-inflammatory Activities. Bioproc. Biosyst Eng 41 (1), 21-30. doi:10.1007/s00449-017-1840-9

Ruszkiewicz, J. A., Pinkas, A., Ferrer, B., Peres, T. V., Tsatsakis, A., and Aschner, M. (2017). Neurotoxic Effect of Active Ingredients in Sunscreen Products, a Contemporary Review. Toxicol. Rep. 4, 245-259. doi:10.1016/j.toxrep.2017.05.006

Saha, P., Mandal, S., Das, A., Das, P. C., and Das, S. (2004). Evaluation of the Anticarcinogenic Activity of Swertia Chirata Buch. Ham, an Indian Medicinal Plant, on DMBA-Induced Mouse Skin Carcinogenesis Model. Phytother. Res. 18 (5), 373-378. doi:10.1002/ptr.1436

Sanaeimehr, Z., Javadi, I., and Namvar, F. (2018). Antiangiogenic and Antiapoptotic Effects of green-synthesized Zinc Oxide Nanoparticles Using Sargassum Muticum Algae Extraction. Cancer Nanotechnol 9 (1), 3-16. doi:10.1186/s12645-018-0037-5

Santhoshkumar, J., Kumar, S. V., and Rajeshkumar, S. (2017). Synthesis of Zinc Oxide Nanoparticles Using Plant Leaf Extract Against Urinary Tract Infection Pathogen. Resource-Efficient Technologies 3 (4), 459-465.

Selim, Y. A., Azb, M. A., Ragab, I., and H M Abd El-Azim, M. (2020). Green Synthesis of Zinc Oxide Nanoparticles Using Aqueous Extract of Deverra Tortuosa and Their Cytotoxic Activities. Sci. Rep. 10 (1), 3445-3449. doi:10.1038/s41598-020-60541-1
Seshadri, V. D. (2021). Zinc Oxide Nanoparticles From Cassia Auriculata Flowers Showed the Potent Antimicrobial and in vitro Anticancer Activity Against the Osteosarcoma MG-63 Cells. Saudi J. Biol. Sci. 28 (7), 4046-4054. doi:10.1016/j.sjbs.2021.04.001

Shandiz, S. A. S., Sharifian, F., Behboodi, S., Ghodratpour, F., and Baghbani-Arani, F. (2021). Evaluation of Metastasis Suppressor Genes Expression and In Vitro Anti-cancer Effects of Zinc Oxide Nanoparticles in Human Breast Cancer Cell Lines MCF-7 and T47D. Avicenna J. Med. Biotechnol. 13 (1), 9. doi:10.18502/ajmb.v13i1.4576

Siddiquah, A., Hashmi, S. S., Mushtaq, S., Renouard, S., Blondeau, J. P., Abbasi, R., et al. (2018). Exploiting In Vitro Potential and Characterization of Surface Modified Zinc Oxide Nanoparticles of Isodon Rugosus Extract: Their Clinical Potential towards HepG2 Cell Line and Human Pathogenic Bacteria. EXCLI J. 17, 671-687. doi:10.17179/excli2018-1327

Sundrarajan, M., Ambika, S., and Bharathi, K. (2015). Plant-extract Mediated Synthesis of ZnO Nanoparticles Using Pongamia Pinnata and Their Activity against Pathogenic Bacteria. Adv. powder Technol. 26 (5), 1294-1299. doi:10.1016/j.apt.2015.07.001

Verma, S. K., Panda, P. K., Jha, E., Suar, M., and Parashar, S. K. S. (2017). Altered Physiochemical Properties in Industrially Synthesized $\mathrm{ZnO}$ Nanoparticles Regulate Oxidative Stress; Induce In Vivo Cytotoxicity in Embryonic Zebrafish by Apoptosis. Sci. Rep. 7 (1), 13909-13916. doi:10.1038/s41598-017-14039-y

Verma, S. K., Jha, E., Kiran, K. J., Bhat, S., Suar, M., and Mohanty, P. S. (2016). Synthesis and Characterization of Novel Polymer-Hybrid Silver Nanoparticles and its Biomedical Study. Mater. Today Proc. 3 (6), 1949-1957. doi:10.1016/j.matpr.2016.04.096

Verma, S. K., Jha, E., Panda, P. K., Kumari, P., Pramanik, N., Kumari, S., et al. (2018a). Molecular Investigation to RNA and Protein Based Interaction Induced In Vivo Biocompatibility of Phytofabricated AuNP with Embryonic Zebrafish. Artif. Cell nanomedicine, Biotechnol. 46 (Suppl. 3), S671-S684. doi:10.1080/21691401.2018.1505746

Verma, S. K., Jha, E., Panda, P. K., Thirumurugan, A., Patro, S., Parashar, S. K. S., et al. (2018b). Molecular Insights to Alkaline Based Bio-Fabrication of Silver Nanoparticles for Inverse Cytotoxicity and Enhanced Antibacterial Activity. Mater. Sci. Eng. C 92, 807-818. doi:10.1016/j.msec.2018.07.037

Wahab, R., Kaushik, N. K., Verma, A. K., Mishra, A., Hwang, I. H., Yang, Y.-B., et al. (2011). Fabrication and Growth Mechanism of $\mathrm{ZnO}$ Nanostructures and Their Cytotoxic Effect on Human Brain Tumor U87, Cervical Cancer HeLa, and normal HEK Cells. J. Biol. Inorg. Chem. 16 (3), 431-442. doi:10.1007/s00775-010-0740-0

Wawrosch, C., Hugh-Bloch, A., Hostettmann, K., and Kopp, B. (2005). Swertia Chirata Buch.-Ham. Ex Wall. (Gentianaceae), an Endangered Himalayan Medicinal Plant: Comparative Study of the Secondary Compound Patterns in Market Drua. In Vitro-Cultivated, and Micropropagated Field Grown Samples. Sci. Pharm. 73 (3), 127-137. doi:10.3797/scipharm.aut-05-11

Wijesinghe, U., Thiripuranathar, G., Iqbal, H., and Menaa, F. (2021). Biomimetic Synthesis, Characterization, and Evaluation of Fluorescence Resonance Energy Transfer, Photoluminescence, and Photocatalytic Activity of Zinc Oxide Nanoparticles. Sustainability 13 (4), 2004. doi:10.3390/su13042004

Zhu, T., Li, X., Luo, L., Wang, X., Li, Z., Xie, P., et al. (2015). Reversion of Malignant Phenotypes of Human Glioblastoma Cells by $\beta$-elemene through $\beta$-cateninmediated Regulation of Stemness-, Differentiation- and Epithelial-ToMesenchymal Transition-Related Molecules. J. Transl Med. 13 (1), 356-414. doi:10.1186/s12967-015-0727-2

Conflict of Interest: The authors declare that the research was conducted in the absence of any commercial or financial relationships that could be construed as a potential conflict of interest.

Publisher's Note: All claims expressed in this article are solely those of the authors and do not necessarily represent those of their affiliated organizations, or those of the publisher, the editors, and the reviewers. Any product that may be evaluated in this article, or claim that may be made by its manufacturer, is not guaranteed or endorsed by the publisher.

Copyright (c) 2021 Berehu, S, Khan, Chakraborty, Lavudi, Penchalaneni, Mohapatra, Mishra and Patnaik. This is an open-access article distributed under the terms of the Creative Commons Attribution License (CC BY). The use, distribution or reproduction in other forums is permitted, provided the original author(s) and the copyright owner(s) are credited and that the original publication in this journal is cited, in accordance with accepted academic practice. No use, distribution or reproduction is permitted which does not comply with these terms. 